\title{
Pengaruh Kualitas Layanan ,Citra Merek Dan Kepercayaan Terhadap Minat Beli Online Produk Batik Tulis Mutiara Sendang Lamongan
}

\author{
Ahmad Fathur Rozi ${ }^{1}$, Nasikan ${ }^{2}$ \\ 1,2 Fakultas Ekonomi Universitas Islam Darul Ulum Lamongan
}

\begin{tabular}{|c|c|}
\hline INFO ARTIKEL & Abstract \\
\hline $\begin{array}{l}\text { Sejarah Artikel: } \\
\text { Diterima }: 2020 \\
\text { Diperbaiki : } 2020 \\
\text { Disetujui }: 2020 \\
\end{array}$ & \multirow[b]{2}{*}{$\begin{array}{l}\text { This research to analyze the effect of service quality, brand image and } \\
\text { trust on buying interest online of Batik Tulis at Mutiara Sendang } \\
\text { Lamongan. } \\
\text { The sampling technique used was purposive sampling and } \\
\text { Convinience Sampling. This study used 99 respondents } \\
\text { The research approach used is quantitative research while the type of } \\
\text { research is explanatory research. The instrument test technique used is } \\
\text { the validity test and reliability test, while the data analysis uses } \\
\text { multiple linear regression and and classical assumption test., The } \\
\text { hypothesis testing uses (F test and T test). and R Determination with } \\
\text { IBM SPSS } 23 \text { calculation. } \\
\text { Based on the research results obtained the Service Quality variable } \\
\text { (X1) obtained tcount> ttable (3.952> 1.985), meaning that Service } \\
\text { Quality has a significant effect on Buying Interest Online, Brand } \\
\text { Image Variables obtained tcount> ttable (4.201> 1.985) meaning } \\
\text { Brand Image has a significant effect. on Buying Interest Online, while } \\
\text { Trust (X3) obtained tcount> ttable (4.151> 1.985), meaning that trust } \\
\text { has a significant effect on Buying Interest Online, based on the F test } \\
\text { it is obtained F count = 85.231> F table = 2.47 it can be stated that, } \\
\text { simultaneously, Quality Service (X1), Brand Image (X2) and Trust } \\
\text { (X3) have a significant effect on Online Purchase Interest (Y), while } \\
\text { the most influential variable is the Brand Image variable (X2) }\end{array}$} \\
\hline \multirow[t]{2}{*}{$\begin{array}{l}\text { Keywords: } \\
\text { Service Quality, Brand Image, } \\
\text { Trust and Buying Interest } \\
\text { Online }\end{array}$} & \\
\hline & Abstraks \\
\hline $\begin{array}{l}\text { Kata Kunci: } \\
\text { Kualitas Layanan, Citra Merek, } \\
\text { Kepercayaan dan Minat Beli } \\
\text { Online }\end{array}$ & $\begin{array}{l}\text { Penelitian ini bertujuan menganalisa Pengaruh Kualitas } \\
\text { Layanan, Citra Merek dan Kepercayaan Terhadap Minat Beli } \\
\text { online batik tulis di Mutiara Sendang Lamongan. } \\
\text { Teknik pengambilan sampel vang digunakan adalah }\end{array}$ \\
\hline DOI: & $\begin{array}{l}\text { pengambilan sampel dengan cara Purposive Sampling dan } \\
\text { Convinience Sampling. Penelitian ini menggunkan } 99 \\
\text { responden } \\
\text { Pendekatan penelitian yang digunakan adalah penelitian } \\
\text { kuantitatif sedangkan jenis penelitiannya adalah eksplanatory } \\
\text { research Adapun Tehnik Uji Instrumen yang digunakan adalah } \\
\text { Uji Validitas dan Uji reabilitas ,Sedang analisis Data } \\
\text { menggunakan regresi linear berganda dan dan uji asumsi } \\
\text { klasik., uji hipotesis menggunakan (uji F dan uji T) serta R } \\
\text { Determinasi dengan perhitungan SPSS 23 IBM. }\end{array}$ \\
\hline
\end{tabular}




\begin{tabular}{|l|l|}
\hline & Berdasarkan hasil penelitian diperolah variabel Kualitas \\
& Layanan (X1) diperoleh nilai thitung $>$ ttabel $(3.952>1.985)$ \\
artinya Kualitas Layanan berpengaruh secara signifikan \\
terhadap Minat Beli Online, Variabel Citra Merek diperoleh nilai \\
thitung $>$ ttabel $(4.201>1.985)$ artinya Citra Merek berpengaruh \\
secara signifikan terhadap Minat Beli Online, sedangkan \\
Kepercayaan (X3) diperoleh nilai thitung> ttabel (4.151 > 1.985) \\
artinya Kepercayaan berpengaruh secara signifikan terhadap \\
Minat Beli Online, berdasarkan uji F diperoleh F hitung = \\
85.231> F tabel =2.47 dapat dinyatakan bahwa, secara simultan \\
Kualitas Layanan (X1), Citra Merek (X2) dan Kepercayaan(X3) \\
berpengaruh signifikan terhadap Minat Beli Online(Y), \\
Sedangkan variabel yang paling berpengaruh adalah variabel \\
Citra Merek (X2)
\end{tabular}

\section{PENDAHULUAN}

Seiring dengan berkembangnya Pada dasarnya setiap pengusaha menginginkan usahanya bisa berjalan dengan lancar, memperoleh keuntungan yang besar maupun mendapatkan apa yang menjadi tujuannya. Namun hal tersebut bukanlah suatu hal yang mudah untuk diraih, diperlukan usaha keras dari pemilik perusahaan dalam pengelolaannya. Dimana dunia usaha merupakan lingkungan dinamis, lingkungan yang mudah berubah setiap saat. Saat ini perkembangan perekonomian dunia menuju kearah globalisasi, sebuah era yang menginginkan keterbukaan dan kebebasan dalam berbisnis. Hal ini akan berdampak pada persaingan bisnis yang semakin ketat, semakin banyak produk yang ditawarkan serta tuntutan kebutuhan konsumen yang semakin rasional.

Kemajuan teknologi saat ini memberikan manfaat dan kemudahan dalam berbagai aktivitas sehari-hari. Aktivitas bisnis melalui media internet merupakan salah satu pemanfaatan teknologi. Internet merupakan sarana elektronik yang dapat dipergunakan untuk berbagai aktivitas seperti komunikasi, riset, dan transaksi bisnis. Penjualan produk di internet akan mengubah cara pembelian pemasaran (Lupiyoadi, 2013).

Kualitas layanan atau jasa adalah setiap tindakan atau kinerja yang ditawarkan oleh satu pihak ke pihak lain yang secara prinsip tidak berwujud dan tidak menyebabkan perpindahan kepemilikan. Jadi dapat disimpulkan bahwa pelayanan atau jasa adalah sesuatu yang diberikan oleh suatu pihak kepada pihak lain yang pada dasarnya tidak berwujud dan tidak mengakibatkan terjadinya perpindahan kepemilikan apapun sehingga hanya dapat diukur dari kepuasan konsumen yang didapat dari kualitas pelayanan yang diberikan oleh penjual (Kotler,2013).

Kepercayaan Konsumen Mutiara Sendang masih dirasa belum sesuai dengan alasan bahwa kesediaan Konsumen pada umumnya bergantung pada kemampuan Merek untuk melaksanakan fungsinya,belum ditemukan secara nyata oleh Konsumen Mutiara Sendang. Dimana lebih fokus membangun kualitas hubungan relationship dengan Konsumen untuk dapat melayani agar menghasilkan retensi dan Minat Beli OnlineKonsumen. Mutiara Sendang memperkirakan bahwa Konsumen masih memiliki pengalaman Merek dengan tingkat rendah yang mengakibatkan hubungan relationship rendah dengan merek. fokus membangun komitmen yang diperlukan untuk mengurangi ketidakpastian hubungan relationship dan menghemat biaya untuk Konsumen mencari informasi dengan merek lain.

Disisi yang lain konsumen yang merasa memiliki kualitas hubungan tingka ttinggi lebih mungkin untuk mengambil tindakan penolakan keras jika mereka memiliki peristiwa negatif dengan merek. Ketika seorang Konsumen merasa baik tentang hubungan dengan merek, maka tingkat 
komitmen yang tinggi dan loyalitas hasil menunjukkan bahwa pengalaman merek yang positif pada Konsumen dapat mempengaruhi kognisi terhadap merek, komitmen, niat pembelian dan reputasi merek. Lee, HJ. \& Kang, MS. (2012).

Minat merupakan ketertarikan konsumen terhadap suatu produk dengan mencari informasi tambahan (Schiffman \& Kanuk, 2004). Seorang konsumen yang mulai timbul minatnya akan terdorong untuk mengetahui kualitas toko online, kemudian konsumen akan membangun kepercayaan atas hasil informasi yang didapat dan mempertimbangkan risiko yang dapat ditimbulkan (Setiadi, 2008).

Perusahaan hidup dan berkembang dalam suatu lingkungan yang mengitarinya, sehingga faktor lingkungan perlu mendapat perhatian dalam pembuatan keputusan dibidang pemasaran (Kotler , 2011: 18 ).

Disisi lain perkembangan UMKM khususnya UKM diharapkan akan meningkatkan stabilitas ekonomi makro, karena menggunakan bahan baku lokal dan memiliki potensi ekspor, sehingga akan membantu menstabilkan kurs rupiah dan tingkat inflasi. Pemberdayaan UKM akan menggerakkan sektor riil, karena UKM umumnya memiliki keterkaitan industri yang cukup tinggi. UKM diharapkan menjadi tumpuan pengembangan di sektor perbankan yang kuat dan sehat pada masa mendatang, mengingat non-performing loannya yang sangat rendah. Pemberdayaan UKM juga akan meningkatkan pencapaian sasaran pembangunan untuk kesejahtera kesejahteraan masyarakat Indonesia.

Batik Indonesia sudah diakui dunia dan dicintai di seluruh dunia, tak terhitung berbagai macam batik yang dimiliki bangsa Indonesia, mulai dari daerah asal, motif, proses, dan bahan. Salah satunya jenis batik yang mulai menunjukkan eksistensisnya adalah batik tulis Lamongan.

"MUTIARA SENDANG" merupakan produsen batik Lamongan dengan alamat Jalan Sunan Muria No. 7, Sendangduwur, Paciran, Sendangduwur, Lamongan, Kabupaten Lamongan, Jawa Timur 62264 . Adapun tujuan Penjualan produk langsung kepada para Penjual Eceran, Resseller, Grosir, distributor, Toko dan online dengan daerah pemasaran meliputi di seluruh kota di Indonesia

Permasalahan terjadi pada industri kecil bati tulis di Sendang Kecamatan Paciran Kabupaten Lamongan yang selama ini sudah lama bergerak dalam bidang tersebut. volume penjualan yang dicapai merosot pada tahun 2016, dan terdapat indikasi bahwa hasil penjualan yang dicapai oleh perusahaan tersebut sampai dengan awal januari 2019 relatif agak lambat terangkat naik.

Dengan adanya penurunan volume tersebut mengakibatkan perkembangan industri akan lambat.

Untuk itulah peneliti tertarik untuk melakukan penelitian dengan judul " Pengaruh Kualitas Layanan ,Citra Merek Dan Kepercayaan Terhadap Minat Beli Online Produk Batik Tulis Mutiara Sendang Lamongan

\section{TINJAUAN PUSTAKA}

\subsection{Kualitas layanan}

\section{a. Konsep kualitas pelayanan}

Menurut American Society for Quality Control, kualitas adalah keseluruhan ciri- ciri dan karakteristik dari suatu produk / jasa dalam hal kemampuannya untuk memenuhi kebutuhan yang telah ditentukan atau bersifat laten (Lupiyoadi, 2011:154). Goetsch dan David dalam Mauludin (2010:38) mengatakan kualitas merupakan suatu kondisi dinamis yang berhubungan dengan produk, manusia, proses dan lingkungan yang memenuhi harapan. Juran dan Wijono dalam Mauludin (2010:39) menyatakan kualitas merupakan perwujudan atau gambaran-gambaran hasil yang mempertemukan kebutuhan-kebutuhan dari pelanggan dalam memberikan kepuasan.

Berdasarkan beberapa definisi di atas dapat diambil kesimpulan bahwa kualitas merupakan suatu hasil yang mempertemukan kebutuhan-kebutuhan dari pelanggan dalam memberikan kepuasan dan memenuhi harapan. Untuk memberikan pelayanan yang baik dibutuhkan kesungguhan yang mengandung unsur kecepatan, keamanan, keramahtamahan, dan kenyamanan yang terintegrasi sehingga manfaatnya besar. Pelayanan adalah setiap kegiatan dan manfaat yang dapat diberikan oleh suatu pihak ke pihak lain yang pada 
dasarnya tidak berwujud dan tidak perlu berakibat pemilikan sesuatu (Kotler, 2013 : 352).

Sedangkan pelayanan oleh Gasper dalam Mauludin (2010:41) didefinisikan sebagai aktivitas pada keterkaitan antara pemasok dan pelanggan untuk memenuhi kebutuhan pelanggan. Pelayanan pelanggan yang bermutu membuat pengertian ekonomi sumber kehidupan perusahaan adalah bisnis yang berulang. Meluaskan basis pelanggan adalah vital ini berarti perusahaan tidak harus menarik klien atau pelanggan baru, tetapi juga harus mempertahankan yang sudah ada.

Berdasarkan beberapa definisi di atas dapat disimpulkan bahwa pelayanan merupakan suatu tindakan seseorang terhadap orang lain melalui penyajian produk sesuai dengan ukuran berlaku pada produk untuk memenuhi kebutuhan, keinginan dan harapan orang yang dilayani

\subsubsection{Definisi}

kualitas jasa berpusat pada upaya pemenuhan kebutuhan dan keinginan pelanggan serta ketepatan penyampaiannya untuk mengimbangi harapan pelanggan. Menurut Wyckof, Lovelock (1988) dalam Tjiptono (2008 : 59), kualitas jasa adalah tingkat keunggulan yang diharapkan dan pengendalian atas tingkat keunggulan tersebut untuk memenuhi keinginan pelanggan. Menurut Parasuraman, et al (1985) dalam Tjiptono (2008: 60) ada dua faktor utama yang mempengaruhi kualitas jasa yaitu expected service (jasa yang diharapkan) dan perceived service (jasa yang diterima). Apabila jasa yang diterima atau yang dirasakan sesuai dengan yang diharapkan, maka kualitas jasa dipersepsikan baik dan memuaskan. Jika jasa yang diterima melampaui harapan pelanggan, maka kualitas jasa dipersepsikan sebagai kualitas yang ideal. Sebaliknya jika jasa yang diterima lebih rendah dari pada yang diharapkan, maka kualitas jasa akan dipersepsikan buruk atau tidak memuaskan.Dengan demikian baik tidaknya kualitas jasa tergantung pada kemampuan pada penyediaan jasa dalam memenuhi harapan pemakainya secara konsisten.

Parasuraman dalam Pujawan dalam Mauludin (2010:39) mengemukaan bahwa kualitas pelayanan merupakan ukuran penilaian menyeluruh atas tingkat suatu pelayanan yang baik. Sedangkan Gronroos et.al dalam Pujawan (2007) mendefinisikan kualitas pelayanan (Service quality) sebagai hasil persepsi dari perbandingan antara harapan pelanggan dengan kinerja aktual pelayanan.

Berdasarkan definisi di atas dapat disimpulkan bahwa kualitas pelayanan merupakan suatu penilaian terhadap harapan pelanggan dengan hasil kinerja pelayanan. Selanjutnya Elhaitammy dan Parani dalam Mauludin (2010:39), mengemukakan tentang pengertian pelayanan jasa yang unggul (Service excellence) yaitu suatu sikap atau cara karyawan dalam melayani pelanggan secara memuaskan.

Sasaran dan manfaat dari jasa yang unggul secara garis besar terdapat empat unsure pokok yaitu : kecepatan, ketepatan, keramahan, dan kenyamanan. Keempat unsure pokok tersebut merupakan suatu kesatuan pelayanan yang terintegrasi, artinya pelayanan atau jasa menjadi tidak sempurna bila ada salah satu dari unsur tersebut diabaikan. Untuk mencapai hasil yang unggul, setiap karyawan harus memiliki ketrampilan tersebut, di antaranya berpenampilan baik serta berpenampilan ramah, memperlihatkan gairah kerja dan selalu siap melayani, tenang dalam bekerja, tidak tinggi hati karena merasa dibutuhkan, menguasai pekerjaan dengan baik maupun kemampuan untuk berkomunikasi dengan baik, bisa memahami bahasa isyarat dan yang penting adalah mampu menangani keluhan pelanggan secara baik.

\subsection{Citra Merek}

Sebuah merek yang terkenal dan terpercaya merupakan aset yang tidak ternilai. Keahlian yang paling unik dari pemasaran yang professional adalah kemampuannya untuk menciptakan, memelihara, melindungi, dan meningkatkan merek. Menurut Kotler dalam Fandy Tjiptono (2015 : 105) menyusun paham bahwa ada enam makna yang bisa di sampaikan melalui suatu merek, yaitu pada halaman selanjutnya :

1. Sarana identifikasi untuk memudahkan proses penanganan atau pelacakan produk bagi perusahaan. 
2. Bentuk proteksi hukum terhadap fitur atau aspek produk yang unik.

3. Signal tingkat kualitas bagi para pelanggan yang puas, signal tingkat kualitas bagi para pelanggan yang puas, sehingga mereka bisa dengan mudah memilih dan membelinya lagi di lain waktu.

4. Sarana menciptakan asosiasi dan makna unik yang membedakan produk dari para pesaing.

5. Sumber keunggulan kompetitif, terutama melalui perlindungan hukum, loyalitas pelanggan, dan citra unik yang berbentuk dalam benak konsumen.

6. Sumber finansial returns terutama menyangkut pendapatan masa depan.

Dari definisi oleh para ahli di atas dan halaman sebelumnya, dapat disimpulkan bahwa merek adalah sebuah tanda yang berupa gambar, nama, kata, huruf-huruf, angka-angka, susunan warna atau kombinasi dari unsur-unsur tersebut atau simbol yang memiliki daya pembeda dan digunakan dalam kegiatan perdagangan barang dan jasa.

Menurut Kotler (2013:418) merek yang baik mempunyai enam tingkatan pengertian, yaitu:

1. Atribut, ada sesuatu atribut yang meletkat pada produk mereka.

2. Manfaat, kata atribut dapat diartikan sebagai manfaat fungsional dan emosional.

Istilah tahan lama dapat dikatakan sebagai manfaat fungsional, sedangkan barang mahal dapat diartikan sebagai manfaat emosional .Biar mahal tapi produk itu menguntungkan.

1. Nilai,

2. Kebudayaan,

3. Kepribadian

4. Pengguna atau pemakai

\subsection{Kepercayaan}

Menurut Ganesan dan Shankar dalam Farida Jasfar (2009: 165 ) menjelaskan bahwa kepercayaan itu merupakan refleksi dari dua komponen, yaitu:

1. Credibility

2. Benevolence

Pelanggan yang memiliki sikap percaya kepada produsen akan memberikan keuntungan bagi produsen ,menurut (Zeithhaml dan Bitner, 2003:159-162) produsen akan memperoleh:

1. Pembelian yang meningkat.
2. Biaya lebih rendah

3. Retensi karyawan

b. Jenis - Jenis kepercayaan

Seorang membentuk 3 jenis kepercayaan (three types of belief) Jhon C Mowen/Michael Minor (2002 : 312) yaitu :

1. Kepercayaan atribut objek

2. Kepercayaan atribut manfaat

3. Kepercayaan objek manfaat .

c. Faktor-faktor yang mempengaruhi Kepercayaan

Menurut Pappers dan Roggers (2004: 45) faktor-faktor yang mempengaruhi kepercayaan, antara lain:

1. Nilai

2. Ketergantungan pada pihak lain mengimplikasikan kerentanan.

3. Komunikasi yang terbuka dan teratur

\subsection{Minat Beli}

Griffin (2013:33-34) menyatakan bahwa "pelanggan yang merasa puas dengan produk atau jasa yang telah dibeli maka akan melakukan pembelian kembali".

Menurut Peter dan Olson (2011:110)"

konsumen melakukan pembelian ulang karena adanya suatu dorongan dan perilaku membeli secara berulang yang dapat menumbuhkan suatu loyalitas terhadap apa yang dirasakan sesuai untuk dirinya. Jadi, minat beli ulang dapat disimpulkan sebagai suatu kecenderungan untuk melakukan pembelian ulang, serta memperoleh respon positif atas tindakan masa lalu".

Terdapat perbedaan antara pembelian aktual yang benar- benar dilakukan oleh konsumen dengan minat beli ulang. Minat beli ulang adalah "kecenderungan pembelian dimasa dating". Meskipun pembelian tersebut belum tentu dilakukan dimasa mendatang, namun pengukuran terhadap kecenderungan pembelian umumnya dilakukan guna memaksimumkan prediksi terhadap pembelian itu sendiri.

Kotler dan Keller ( 2009: 244) berpendapat bahwa "setelah konsumen membeli produk tersebut, konsumen bisa puas atau tidak puas dan terlibat dalam perilaku pasca pembelian. Pelanggan yang puas akan kembali membeli produk, memuji produk yang membelinya dihadapan orang 
lain, sedikit menarik perhatian pada merek dan iklan pesaing dan membeli produk lain dari perusahaan yang sama".

Menurut Suryani (2008:131) bahwa "melakukan pembelian secara teratur (pembelian ulang) adalah pelanggan yang telah melakukan pembelian suatu produk sebanyak dua kali atau lebih secara teratur".

Dari beberapa definisi mengenai minat beli ulang diatas maka dapat disimpulkan bahwa "minat beli ulang merupakan kegiatan pembelian yang dilakukan konsumen setelah mereka melakukan pembelian yang pertama kali dari produk maupun jasa yang dilakukan secara berulang pada jangka waktu tertentu dan secara aktif menyukai dan mempunyai sikap positif terhadap suatu produk barang / jasa, didasarkan pada pengalaman yang telah dilakukan dimasa lampau".

2. Faktor - faktor yang mempengaruhi minat beli ulang:

Menurut Kotler (2011:145), ada beberapa faktor utama yang mempengaruhi minat seseorang untuk melakukan pembelian ulang, yaitu:

\section{Faktor Psikologis}

Meliputi pengalaman belajar individu tentang kejadian di masa lalu, serta pengaruh sikap dan keyakinan individu. Pengalaman belajar dapat didefinisikan sebagai suatu perubahan perilaku akibat pengalaman sebelumnya. Timbulnya minat konsumen untuk melakukan pembelian ulang sangat dipengaruhi oleh pengalaman belajar individu dan pengalaman belajar konsumen yang akan menentukan tindakan dan pengambilan keputusan membeli. Hal ini dapat dipelajari dari beberapa teori berkut ini:

\section{a. Teori Stimulus Respon}

Berdasarkan teori stimulus respon dari B.F Skinner, dapat disimpulkan bahwa konsumen akan merasa puas jika mendapatkan produk, merek, pelayanan yang menyenangkan. Dan sebaliknya jika produk, merek dan layanan diperoleh konsumen dengan tidak menyenangkan, akan menjadikan konsumen merasa tidak puas.

\section{b. Teori Kognitif}

Berdasarkan teori kognitif dari Heider \& Festinger, perilaku kebiasaan merupakan akibat dari proses berpikir dan orientasi dalam mencapai suatu tujuan. Berdasarkan teori ini dapat disimpulkan bahwa keputusan konsumen sangat dipengaruhi oleh memorinya terhadap sesuatu yang terjadi pada masa lampau, masa sekarang dan masa yang akan datang.

\section{c. Teori Gestalt dan Teori Lapangan}

Berdasarkan teori Gestalt dan teori lapangan, dapat disimpulkan bahwa faktor lingkungan merupakan kekuatan yang sangat berpengaruh pada minat konsumen untuk mengadakan suatu pembelian. Penggunan objek secara keseluruhan akan lebih baik daripada hanya bagian- bagiannya saja. Misalnya, melayani pembeli secara "sempurna", dari awal konsumen masuk pada suatu rumah makan sampai pada saat ia meninggalkan rumah makan tersebut, akan meninggalkan penilaian positif dimata konsumen. Dalam hubungan dengan minat beli ulang, sikap dan keyakinan individu akan pelayanan sebelumnya sangat berpengaruh dalam menentukan apakah individu tersebut suka dengan apa yang ditampilkan sebelumnya, atau sebaliknya, individu memilih untuk mencari tempat makan lain yang dapat memenuhi seleranya

\section{Faktor Pribadi}

Kepribadian konsumen akan mempengaruhi persepsi dan pengambilan keputusan dalam membeli. Oleh karena itu, peranan pramuniaga toko penting dalam memberikan pelayanan yang baik kepada konsumen. Faktor pribadi ini termaswuk di dalamnya konsep diri. Konsep diri dapat didefinisikan sebagai cara kita melihat diri sendiri dan dalam waktu tertentu sebagai gambaran tentang upah yang kita pikirkan. Dalam hubungan dengan minat beli ulang, produsen perlu menciptakan situasi yang diharapkan konsumen. Begitu pula menyediakan dan melayani konsumen dengan produk dan merek yang sesuai dengan yang diharapkan konsumen.

\section{Faktor Sosial}

Mencakup faktor kelompok anutan (small reference group). Kelompok anutan didefinisikan sebagai suatu kelompok orang yang mempengaruhi sikap, pendapat, norma 
dan perilaku konsumen. Kelompok anutan ini merupakan kumpulan keluarga, kelompok atau orang tertentu. Dalam menganalisis minat beli ulang, faktor keluarga berperan sebagai pengambil keputusan, pengambil inisiatif, pemberi pengaruh dalam Minat Beli Online, penentu apa yang dibeli, siapa yang melakukan pembelian dan siapa yang menjadi pengguna. Menurut Kotler (2011:158) mengatakan "anggota keluarga merupakan kelompok acuan primer yang paling berpengaruh". Pengaruh kelompok acuan terhadap minat beli ulang anatara lain dalam menentukan produk dan merek yang mereka gunakan yang sesuai dengan aspirasi kelompoknya. Keefektifan pengaruh niat beli ulang dari kelompok anutan sangat tergantung pada kualitas produksi dan informasi yang tersedia pada konsumen.

Menurut Devlin yang disadur oleh Hadi, Sumarto (2010) dalam jurnal yang berjudul "Pentingnya Brand Loyalty terhadap Minat Beli Ulang" menyebutkan bahwa: Customer service merupakan salah satu strategi positioning. Customer service dan customer communication decision merupakan salah satu indikator strategi positioning. Pelayanan yang memuaskan bagi pelanggan bisa di lihat dari cara penyampaian karyawan kepada pelanggan, bila pelanggan tidak merasa kesulitan untuk mendapat fasilitas layanan maka pelanggan akan balik lagi untuk berkunjung dan akan memilih tempat tersebut untuk arena kunjungan mereka.

\section{METODE PENELITIAN}

\subsection{Pendekatan Penelitian}

Tipe penelitian yang digunakan dalam penelitian ini adalah tipe explanatory research. Singarimbun dan Effendi (2008:4) menjelaskan explanatory research yaitu penelitian yang digunakan untuk menjelaskan hubungan kausal antara variabel-variabel melalui pengujian hipotesa yang dirumuskan atau sering kali disebut sebagai penelitian penjelas

\subsection{Subyek penelitian}

\subsubsection{Populasi}

Menurut Sugiyono (2012:112) populasi adalah wilayah generalisasi yang terdiri atas obyek (subyek) yang mempunyai kualitas dan karakteristik tertentu yang ditetapkan oleh peneliti untuk dipelajari dan kemudian ditarik kesimpulan. Jumlah populasi yang diambil untuk menentukan sampel adalah 7.655 responden yang menjadi pelanggan online Batik Mutiara Sendang Paciran Lamongan.

\subsection{Sampel}

Menurut Sugiyono (2012:116) Sample merupakan bagian dari populasi yang dipilih dengan menggunakan aturan-aturan tertentu, yang digunakan untuk mengumpulkan informasi/data yang menggabarkan sifat atau ciri yang dimiliki populasi. Dalam menentukan jumlah sampel penelitian menggunkan rumus slovin, dari umar dalam (Kriyanto, 2012, 89) mengatakan, bahwa batas kesalahan yang ditolerir dalam sebuah penlitian memakai tingkat kesalahan ada yang $1 \%, 2 \%, 3 \%, 4 \%, 5 \%$, dan $10 \%$. Dalam penelitian ini peneliti memakai $10 \%$ rumusnya slovin untuk menentukan jumlah sample adalah :

$$
\mathrm{n}=\underset{1+\mathrm{N}(\mathrm{e}) 2}{\mathrm{~N}}
$$

Keterangan:

$\mathrm{n}=$ ukuran sampel,

$\mathrm{N}=$ ukuran populasi.

$\mathrm{e}=$ persen kelonggaran ketidaktelitian Penghitungan dari rumus ini adalah sebagai berikut:

$$
\begin{aligned}
& \mathrm{n}=\frac{\mathrm{N}}{1+\mathrm{Nde}^{2}}= \\
& \frac{7655}{1+7655(0,10)^{2}}=
\end{aligned}
$$

$=98,77$ (dibulatkan 99)

Berdasarkan perhitungan pengambilan sampel diatas, maka dapat diketahui bahwa jumlah sampel yang digunakan dalam penelitian ini adalah sebanyak 99 responden.

3.4.3 Tehnik Pengambilan sampel Sampel

Dalam penelitian ini digunakan metode pengambilan sampel dengan cara Purposive Sampling dan Convinience Sampling.

Purposive Sampling adalah pemilihan sampel pada konsumen berdasarkan tujuan, sedangkan Convinience Sampling adalah pemilihan sampel kepada konsumen yang mudah ditemui. Sugiyono (2012:322). 
3.3 Jenis dan Sumber Data

Dalam penelitian ini peneliti menggunakan jenis data kuantitatif. Adapun dari sumber data adalah Sumber primer yaitu sumber data yang secara langsung memberikan data kepada pengumpul data (Sugiyono, 2012:225).

\subsection{Instrumen Penelitian}

Mengumpulkan data merupakan pekerjaan yang penting dalam penelitian, karena dengan adanya data yang akurat akan diperoleh hasil yang sesuai dengan kegunaanya yaitu pengumpulan variable tetap mengingat pentingnya arti data penelitian maka dalam penelitian ini menurut sugiyono (2012:130), tehnik pengumpulan data yang digunakan adalah sebagai berikut :

\section{Wawancara ( Interview )}

Adalah tehnik pengumpulan data dengan jalan mengadakan tanya jawab secara lisan yang diarahkan kepada manajemen Mutiara Sendang Paciran Lamongan.

\section{Angket (Quesioner)}

Adalah tehnik pengumpulan data dengan cara mengajukan lembaran angket kepada responden yang berisikan daftar pertanyaan. Metode ini digunakan untuk mendapatkan data angket dari responden yang ada.

$$
\begin{aligned}
& \text { Skala Pengukuran } \\
& \text { bahwa "skala likert digunakan } \\
& \text { mengukur sikap, pendapat dan } \\
& \text { seseorang atau sekelompok orang } \\
& \text { fenomena sosial". Dalam skala likert, } \\
& \text { yang akan diukur dan dijabarkan } \\
& \text { indikator variabel, kemudian } \\
& \text { tersebut dijadikan sebagai titik tol } \\
& \text { menyusun item-item instrumen yan } \\
& \text { berupa pernyataan atau pertanyaan. } \\
& \text { Jawaban kuesioner diberi skor } \\
& \text { berikut: } \\
& \text { a. Sangat Tidak Setuju (STS) } \\
& =\text { diberi skor } 1 \\
& \text { b. Tidak Setuju (TS) } \\
& =\text { diberi skor } 2 \\
& \text { c. Kurang Setuju (KS) } \\
& =\text { diberi skor } 3 \\
& \text { d. Setuju (S) } \\
& =\text { diberi skor } 4 \\
& \text { e. Sangat Setuju (SS) } \\
& =\text { diberi skor } 5
\end{aligned}
$$
a. Sangat Tidak Setuju (STS)$$
\text { = diberi skor } 1
$$$$
\text { b. Tidak Setuju (TS) }
$$$$
=\text { diberi skor } 2
$$
c. Kurang Setuju (KS)$$
=\text { diberi skor } 3
$$
d. Setuju (S)
$=$ diberi skor 4
e. Sangat Setuju (SS)
$=$ diberi skor 5$$
\text { Sugiyono (2012:93) mengemukakan }
$$$$
\text { bahwa "skala likert digunakan untuk }
$$
mengukur sikap, pendapat dan persepsi seseorang atau sekelompok orang tentang fenomena sosial". Dalam skala likert, variabel yang akan diukur dan dijabarkan menjadi indikator variabel, kemudian indikator tersebut dijadikan sebagai titik tolak untuk menyusun item-item instrumen yang dapat berupa pernyataan atau pertanyaan. Adapun Jawaban kuesioner diberi skor sebagai

\subsection{Definisi Operasional Variabel}

Variabel-variabel yang digunakan dalam penelitian ini terdiri dari variabel bebas dan variabel terikat yang antara lain:

1. Variabel dependen/bebas $(X)$

adalah variabel yang menjadi pusat perhatian peneliti.

a. Kualitas layanan (X1)

Kualitas layanan berkaitan erat dengan kepuasan pelanggan dan memberikan dorongan khusus bagi para pelanggan untuk menjalin ikatan relasi saling menguntungkan dalam jangka panjang dengan perusahaan Tjiptono dan Chandra (2011: 172)

Adapun indikatornya meliputi:

1. Bukti langsung

2. Kehandalan

3. Daya tanggap

4. Jaminan

5. Perhatian

(2012:112)

Zeithaml ysng dikutip oleh Umar

b. Citra Merek (X2)

Merek menurut Kotler dan Kelller (2009:

65) yaitu :"Merek adalah nama, istilah,tanda,symbol, rancangan atau kombinasi dari hal-hal tersebut yang dimaksudkan untuk mengindentifikasikan barang atau jasa dari seseorang atau sekelompok penjual untuk membedakan dari produk pesaingnya".

Adapun indikator meliputi :

1. Nama Baik

2. Citra dibanding pesaing

3. Dikenal luas Penelitian Selnes (1993).

c. Kepercayaan / Trust (X3)

Menurut Ganesan dan Shankar dalam Farida Jasfar (2009: 165 ) menjelaskan bahwa kepercayaan itu merupakan refleksi Credibility dan

Benevolence.

Adapun indikator meliputi:

1. Kejujuran (honesty)

2. Kebajikan (benevolence)

3. Kompetensi (competence)

Menurut Flavian dan Giunaliu (2007).

2. Variabel independen /Terikat, Minat beli Online $(\mathrm{Y})$

Menurut Schiffman dan Kanuk (2008:201) menemukakan bahwa minat merupakan salah satu aspek psikologis yang memiliki pengaruh cukup besar terhadap sikap perilaku. Minat beli dapat diartikan 
sebagai suatu sikap senang terhadap suatu objek yang membuat individu berusaha untuk mendapatkan objek tersebut dengan cara membayarnya dengan uang atau pengorbanan. Lucas dan Britt dalam Natali (2008:87) ada beberapa indikator yang terdapat pada Minat Beli antara lain:

1. Ketertarikan (interest)yang menunjukan adanya pemusatan dan perasaan senang.

2. Keingina(desire)ditunjukan dengan adanya dorongan untuk ingin memiliki.

3. Keyakinan (conviction)ditunjukan dengan adanya perasaan percaya diri individu terhadap kualitas, daya guna dan keuntungan dari produk yang akan dibeli.

\subsection{Metode Analisis Data}

1. Uji Instrumen Penelitian

Instrumen penelitian ini memakai kuesioner dalam mengumpulkan data primer, untuk perhitungan penelitian ini menggunakan SPSS 22.0 for windows. Adapun pengujian penelitian ini digunakan uji:

\section{a. Uji Validitas}

Menurut Arikunto (2010:144) Uji Validitas adalah suatu ukuran yang menunjukkan tingkat-tingkat kevalidan dan kesahihan instrumen.Uji validitas digunakan untuk mengukur sah atau valid tidaknya suatu kuesioner. Penelitian di katakan valid jika mampu mengukur yang diinginkan serta dapat mengungkapkan data dari variabel yang diteliti secara tepat

Uji signifikansi dilakukan dengan membandingkan nilai $\mathrm{r}$ hitung dengan nilai $\mathrm{r}$ tabel untuk $\mathrm{df}=\mathrm{n}-\mathrm{k}$ dalam hal ini $\mathrm{n}$ adalah jumlah sample dan $\mathrm{k}$ adalah jumlah variabel bebas. Jika $r$ hitung (dapat dilihat dalam kolom corected item-total corelation) lebih besar dari $r$ tabel (dilihat dari $r$ product moment) dan nilai $r$ positif. Maka butir atau pertanyaan tersebut dikatakan valid

\section{b. Uji Reabilitas}

Reliabilitas dilakukan untuk mengukur data-data yang dihasilkan disebut reliabel atau terpecaya, apabila instrumen itu secara konsistem memunculkan hasil yang sama setiap kali dilakukan pengukuran (Ferdinand, 2014: 218). Rebliabilitas adalah alat untuk mengukur suatu kuesioner yang meruapakan indikator dari variabel atau konstruk (Ghozali, 2013: 52) suatu kuesioner dikatakan reliabel atau handal jika jawaban seseorang terhadap pertanyaan adalah konsisten atau stabil dari waktu ke waktu.

Uji reabilitas dapat dihitung menggunakan aplikasi SPSS. Untuk reabilitas dilakukan dengan menghitung uji statistik Cronbach Aplha. Suatu jonstruk atau variabel dikatakan reliabel jika memberikan Cronbach Aplha >0.70 (Ghozali, 2013: 53).

\section{Uji Asumsi Klasik}

Uji asumsi klasik adalah dimana pengujian ini digunakan untuk memperoleh hasil/nilai yang tidak bias atau estimator linear tidak bias yang terbaik (Best Linear Unbiased Estimator/BLUE). Asumsi klasik tersebut yaitu :

a. Multikolinearitas

Priyatno (2010:81) mengemukakan bahwa :

Multikolinearitas adalah keadaan dimana terjadi hubungan linier yang sempurna atau mendekati sempurna antar variabel independen dalam model regresi. Uji multikolinearitas diperlukan untuk mengetahui ada atau tidaknya hubungan linear antar variabel independen dalam model regresi. Prasyarat yang harus dipenuhi dalam model regresi adalah tidak adanya multikolinearitas.

Uji multikolinearitas dalam penelitian ini adalah dengan melihat nilai Inflation Factor (VIF) pada model regresi. Menurut Santoso dalam Priyatno (2010:81) "pada umumnya jika VIF lebih besar dari 5, maka variabel tersebut mempunyai persoalan multikolinearitas dengan variabel bebas lainnya".

b. Heteroskedastisitas

bahwa :

Priyatno (2010:83) mengemukakan

Heteroskedastisitas adalah keadaan dimana terjadi ketidaksamaan varian dari residual untuk semua pengamatan pada model regresi. Uji heteroskedastisitas digunakan untuk mengetahui ada atau tidaknya ketidaksamaan varian dari residual pada model regresi. Prasyarat yang harus dipenuhi dalam model regresi adalah tidak adanya gejala heteroskedastisitas.

Untuk mendeteksi adanya heteroskedastisitas dilakukan dengan melihat ada tidaknya pola tertentu pada grafik scatterplot, dimana sumbu $X$ adalah $Y$ yang telah diprediksi dan sumbu $\mathrm{X}$ adalah residual 
(Y prediksi - Y sesungguhnya yang telah distudentized).

Dasar pengambilan keputusan :

1. Jika ada pola tertentu, seperti titiktitik (poin-poin) yang ada membentuk suatu pola tertentu yang teratur (bergelombang, melebar kemudian menyempit), maka telah terjadi heteroskedastisitas.

2. Jika tidak ada pola yang jelas, serta titik-titik menyebar di atas dan di bawah angka 0 pada sumbu $Y$, maka tidak terjadi heteroskedastisitas.

c. Uji autokorelasi

Menurut Ghozali

autokorelasi bertujuan untuk menguji apakah dalam model regresi linear ada korelasi antara kesalahan pengganggu pada periode $t$ dengan kesalahan pengganggu pada periode sebelumnya. Jika terjadi korelasi, maka dinamakan ada problem autokorelasi.diperoleh nilai Durbin-Watson (DW) . adapun Kreteria Pengukurannya sebagai berikut :

1. $1,65<\mathrm{DW}<2,35$ maka tidak ada autokorelasi.

2. $1,21<\mathrm{DW}<1,65$ atau $2,35<\mathrm{DW}<$ 2,79 maka tidak dapat disimpulkan

3. DW $<1,21$ atau DW $>2,79$ maka terjadi autokorelasi.

d. Uji Normalitas

Menurut Ghozali (2013: 33) cara normal probability plot yang membandingkan distribusi kumulatif dari data sesungguhnya dengan distribusi kumulatif dari distribusi normal. Distribusi normal akan membentuk satu garis diagonal jika distribusi normal data adalah normal maka garis menggambarkan data. Sesungguhnya akan mengikuti garis diagonalnya atau dengan kata lain media grafik histogram dan grafik Normal plot.

1. Jika data menyebar garis diagonal dan mengikuti arah garis diagonal atau grafik histogram menunjukkan pola distribusi normal maka model regresi memenuhi asumsi normalitas.

2. Jika data menyebar garis diagonal dan mengikuti arah garis diagonal atau grafik histogram tidak menunjukkan pola distribusi normal maka model regresi tidak memenuhi asumsi normalitas.

3.Regresi linier berganda
Yaitu untuk menguji atau melakukan estimasi dari suatu permasalahan yang terdiri lebih dari satu variabel bebas. Secara umum persamaan regresi linier berganda dapat dituliskan sebagai berikut:

$$
\begin{aligned}
& \mathrm{Y}= \square 0+\square 1 \mathrm{X} 1+\square 2 \mathrm{X} 2+\square 3 \mathrm{X} 3+\mathrm{e} \\
& \text { Keterangan: } \\
& \mathrm{Y} \quad=\text { Minat Beli Online } \\
& \mathrm{X} 1=\text { Kualitas layanan } \\
& \mathrm{X} 2=\text { Citra merek } \\
& \mathrm{X} 3 \quad=\text { Kepercayaan }
\end{aligned}
$$$$
\mathrm{e}=\text { Kesalahan penggangu }
$$

(error disturbance) (Sugiyono, 2010:221)

\section{Uji F (Uji Serempak)}

Uji ini digunakan untuk mengetahui pengaruh bersama-sama variabel bebas terhadap varibel terikat. Dimana Fhitung> Ftabel, maka H1 diterima atau secara bersama-sama variabel bebas dapat menerangkan variabel terikatnya secara serentak. Sebaliknya apabila Fhitung< Ftabel, maka H0 diterima atau secara bersama-sama variabel bebas tidak memiliki pengaruh terhadap variabel terikat. Untuk mengetahuinya digunakan probability sebesar $5 \%(a=0,05)$.

- Jika sig > à $(0,05)$, maka H0 diterima H1 ditolak.

- Jika sig < à $(0,05)$, maka H0 ditolak H1 diterima.

\section{Uji T (Uji Parsial)}

Uji ini digunakan untuk mengetahui signifikansi dari pengaruh variabel independen terhadap variabel dependen secara individual dan menganggap dependen yang lain konstan. Signifikansi pengaruh tersebut dapat diestimasi dengan membandingkan antara nilai ttabel dengan nilai thitung.

Apabila nilai thitung > ttabel maka variabel independen secara individual mempengaruhi variabel independen, sebaliknya jika nilai thitung < ttabel maka variabel independen secara individual tidak mempengaruhi variabel dependen.

thitung > ttabel berarti $\mathrm{HO}$ ditolak dan menerima $\mathrm{H} 1$

thitung $<$ ttabel berartiH0 diterima dan menolak H1

Uji T juga bisa dilihat pada tingkat signifikansinya:

- Jika tingkat signifikansi $<0,05$, maka $\mathrm{H} 0$ ditolak dan $\mathrm{H} 1$ diterima 
- Jika tingkat signifikansi $>0,05$, maka $\mathrm{H} 0$ diterima dan $\mathrm{H} 1$ ditolak

5. Uji Koefisien Determinasi ( R2 )

Uji ini untuk mengetahui besarnya deregulasi audit variabel bebas dan variabel tidak bebas secara bersama-sama. Dalam beberapa model biasanya perhitungan R2 adalah kurang dari 1 tetapi yang sering terjadi adalah R2 berada antara 0,2 sampai 0,8 .

\section{HASIL PENELITIAN DAN PEMBAHASAN}

4.1 Hasil Penelitian

1. Karakteristrik Responden.

a.Karakteristik Responden berdasarkan jenis kelamin.

Diketahui bahwa dalam penelitian ini yang menjadi responden terdiri dari laki laki sebanyak $542(42,4 \%)$ orang dan perempuan sebanyak $57(57,6 \%)$ orang. Sehingga ditarik kesimpulan kebanyakan reponden berjenis kelamin perempuan

b. Karakteristik resonden berdasarkan usia

Diketahui bahwa responden yang memiliki usia 20 - 25 tahun sebanyak 33 $(33,3 \%)$. responden yang memiliki usia $26-$ 30 sebanyak 32(32,3\%). responden yang memiliki usia diatas 31 tahun sebanyak 34 $(34,3 \%)$ Sehingga dapat ditarik kesimpulan kebanyakan reponden adalah usia diatas 31 tahun sebanyak 34 (34,3\%).

c. Karakteristik resonden pendidikan

bahwa berdasarkan pendidikan terakhir responden terdapat tamatan SD sebanyak 6 (6\% ) SMP sebanyak 3 (3\%) SMA sebanyak 62 $(62,6 \%)$ S1 sebanyak $19(19,2 \%)$, S2 sebanyak $7(7,1 \%)$ dan S3 sebanyak 2 (2\%). Maka untuk pendidikan terakhir responden dapat ditarik kesimpulan kebanyakan reponden adalah tingkatan SMA sebanyak 62(62,6\%) responden

c. Karakteristik resonden pekerjaan

Dapat diketahui bahwa sebagian besar responden dengan pekerjaan sebagai pegawai Negeri yaitu sebanyak 15 (15,2\%), responden yang mempunyai pekerjaan sebagai pegawai swasta sebanyak $53(53,5 \%)$, responden yang mempunyai pekerjaan sebagai wiraswasta sebanyak $16(16,2 \%)$, responden sebagai Pelajar/ Mahasiswa yaitu sebesar 15 (15,2\%). Hal ini dapat diketahui bahwa responden yang bekerja sebagai pegawai swasta adalah responden terbanyak dengan 53 (53,5\%).. c. Karakteristik resonden penghasilan dapat diketahui bahwa responden dengan pendapatan < Rp. 1.500 .000 sebanyak $10(10,1 \%)$, pendapatan n Rp. 1.500 .000 - Rp. 2.000 .000 sebanyak $15(15,2 \%)$, pendapatan Rp. 2.000 .000 - Rp. 3.000 .000 sebanyak 48 $(48,5 \%)$ dan pendapatan > Rp. 3.000 .000 sebanyak $26(26,3 \%)$ sehingga dapat ditarik kesimpulan bahwa kebanyakan reponden adalah berpendapatan Rp. 2.000 .000 - Rp. 3.000.000 sebanyak $48(48,5 \%)$.

\subsection{Pembahasan}

Analisis Data

a. Uji Validitas berikut ini

Uji validitas digunakan untuk melihat valid tidaknya masing-masing instrument

Tabel 1 Uji Validitas

\begin{tabular}{|c|c|c|}
\hline Variabel & Item & $\mathbf{r}_{\text {hitung }}$ \\
\hline $\begin{array}{c}\text { Kualitas } \\
\text { Layanan(X1) }\end{array}$ & $\mathrm{X} 1.1$ & 0,830 \\
\hline & $\mathrm{X} 1.2$ & 0,816 \\
\hline & $\mathrm{X} 1.4$ & 0,854 \\
\hline Citra Merek (X2) & $\mathrm{X} 2.1$ & 0,830 \\
\hline & $\mathrm{X} 2.2$ & 0,885 \\
\hline & $\mathrm{X} 2.3$ & 0,842 \\
\hline Kepercayaan (X3) & $\mathrm{X} 3.1$ & 0,939 \\
\hline & $\mathrm{X} 3.2$ & 0,838 \\
\hline & $\mathrm{X} 3.3$ & 0,907 \\
\hline Minat Beli & $\mathrm{Y} .1$ & 0,901 \\
\hline online(Y) & $\mathrm{Y} .2$ & 0,919 \\
\hline & $\mathrm{Y} .3$ & 0,871 \\
\hline Sumber: Data Primer & $\mathrm{dioh}$ \\
\hline & 2020 \\
\hline
\end{tabular}

Sumber : Data Primer diolah 2020

Dari hasil tabel diatas, menunjukkan bahwa semua $r$ hitung $>r$ tabel pada nilai signifikasi (0.05) dengan $\mathrm{N}=99$, diperoleh angka 0.197. Dapat diketahui $r$ hitung tiap- 
tiap item > 0.197 Oleh karena itu dapat disimpulkan bahwa semua item dalam angket penelitian ini valid

b. Uji Reliabilitas berikut:

Sedangkan Uji Reabilitas Sebagai

Tabel 2 Uji Reabilitas

\begin{tabular}{|l|c|l|}
\hline \multicolumn{3}{|c|}{ Validitas } \\
\hline Variabel & $\begin{array}{c}\text { Cronbach } \\
\text { Alpha }\end{array}$ & Ket \\
\hline X1 &, 843 & Reliabel \\
\hline X2 &, 810 & Reliabel \\
\hline X3 &, 875 & Reliabel \\
\hline Y &, 862 & Reliabel \\
\hline
\end{tabular}

Sumber : Data Primer diolah 2020

Dari tabel diatas di atas maka Variabel $\mathrm{X} 1, \mathrm{X} 2, \mathrm{X} 3$ dan $\mathrm{Y}$ dapat dikatakan bahwa data yang digunakan reliabel karena nilai Cronbach's Alpha > 0.70.

\section{Uji Analisis Regresi}

Bentuk persamaan pengaruh variabel $X$ terhadap variabel $Y$ adalah sebagai berikut :

Tabel 3 Analisis Regresi

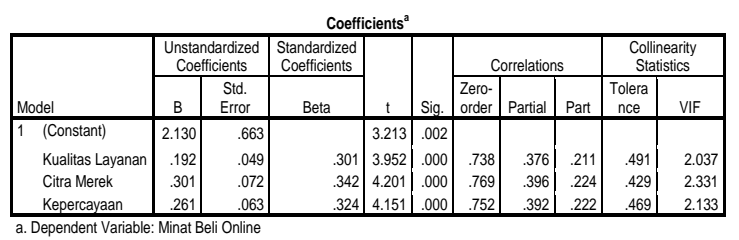

Sumber : Data Primer diolah 2020

Dari tabel di atas, maka persamaan regresi linier berganda yang terbentuk adalah sebagai berikut :

$$
Y=2,130+0,192 X 1+0,301 X 2+
$$
$0,261 X 3+e$

Keterangan :

1. Nilai a (konstanta) sebesar 2,130 artinya jika X1, X2 dan X3 konstan maka Minat Beli online adalah sebesar 2,130 satuan.

2. Koefisien regresi X1 Kualitas Layanan sebesar 0,192 menunjukan bahwa Kualitas Layanan mempunyai pengaruh sebesar 0,192 terhadap Minat Beli online Hal ini berarti peningkatan pengaruh Kualitas Layanan sebesar 1 satuan akan mengakibatkan kenaikan Minat Beli online sebesar 0,192 dengan asumsi X1 konstan dan sebaliknya
3. Koefisien regresi X2 Citra Merek sebesar 0,301 menunjukan bahwa Citra Merekmempunyai pengaruh sebesar 0,301 terhadap Minat Beli online $\mathrm{Hal}$ ini berarti peningkatan pengaruh Citra Merek sebesar 1 satuan akan mengakibatkan kenaikan Minat Beli online sebesar 0,301 dengan asumsi X2 konstan dan sebaliknya

4. Koefisien regresi X3 Kepercayaan sebesar 0,261menunjukan bahwa Kepercayaan mempunyai pengaruh sebesar 0,261terhadap Minat Beli online Hal ini berarti peningkatan pengaruh Kepercayaan sebesar 1 satuan akan mengakibatkan kenaikan Minat Beli online sebesar 0,261 dengan asumsi X3 konstan dan sebaliknya

5. Uji Asumsi klasik

a. Uji Multikolinieritas

Tabel 5 Uji Multikolinieritas

\begin{tabular}{|l|r|r|r|r|r|}
\hline \multirow{2}{*}{ Model } & \multicolumn{3}{|c|}{ Correlations } & \multicolumn{2}{c|}{ Collinearity Statistics } \\
\cline { 2 - 6 } & $\begin{array}{c}\text { Zero- } \\
\text { order }\end{array}$ & Partial & \multicolumn{1}{c|}{ Part } & Tolerance & \multicolumn{1}{c|}{ VIF } \\
\hline $1 \quad$ (Constant) & & & & & \\
Kualitas Layanan & .738 & .376 & .211 & .491 & 2.037 \\
Citra Merek & .769 & .396 & .224 & .429 & 2.331 \\
Kepercayaan & .752 & .392 & .222 & .469 & 2.133 \\
\hline
\end{tabular}

Sumber : Data Primer diolah 2020

Dari tabel diatas menunjukkan bahwa nilai Variance Inflation Factor (VIF) dari masing-masing variabel independen tidak memiliki nilai yang lebih dari 10 sehingga dapat disimpulkan regresi dalam penelitian tidak mendukung multikolonieritas

b. Autokorelasi

Tabel 6 Autokorelasi

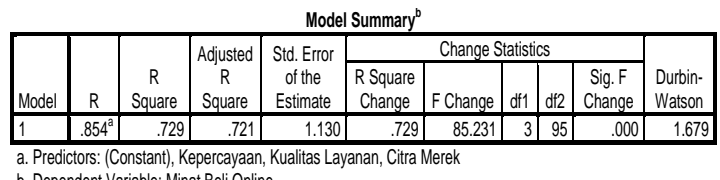

b. Dependent Variable: Minat Beli Online

Sumber : Data Primer diolah 2020

Dari tabel diats menunjukkan bahwa Durbin-Watson 1,679 dan termasuk dalam kategri 1,65< DW $<2,35$ atau 1,65 $<1,679<$ 2,35. Sehingga dapat disimpulkan tidak terdapat autokrelasi dalam penelitian ini.

c. heterokedastisitas

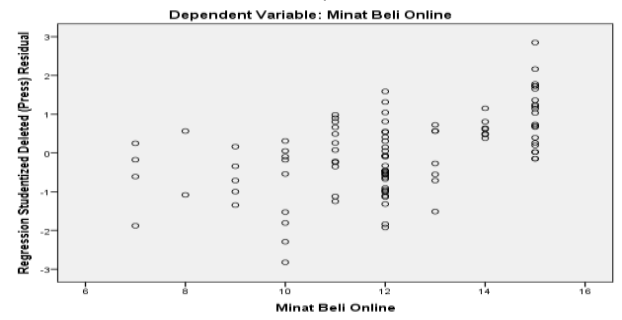


Gambar 1.heterokedastisitas

Dari gambar diatas menunjukkan bahwa penyebaran data menyeluruh pada sampel dan menyebar diatas dan dibawah angka nol pada sumbu Y maka dapat disimpulkan bahwa dalam penelitian ini tidak terdapat heterokedastisitas

\section{C. uji normalitas}

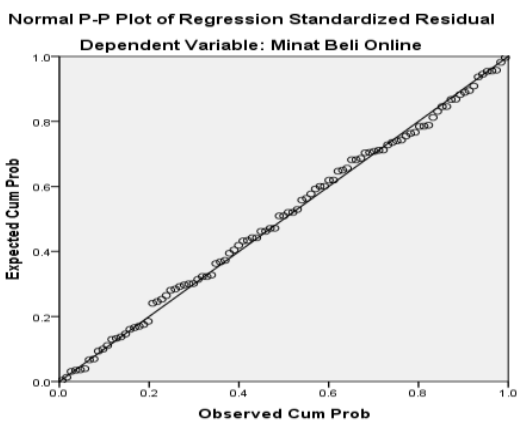

Gambar 2.heterokedastisitas

Dari grafik menunjukkan bahwa gambar mengikuti garis melintang sehingga dapat dikatakan data berdistribusi normal

6. Uji Hipotesis

a. Uji T

Tabel 7 Uji t

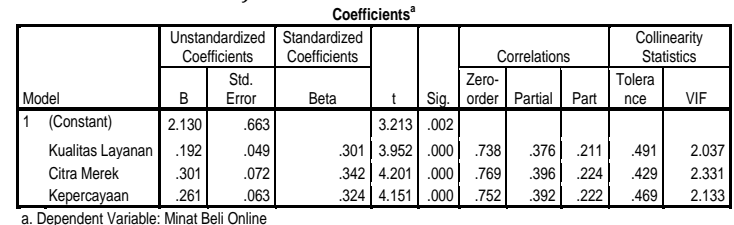

Sumber : Data Primer diolah 2020

Dari tabel diatas dapat disimpulkan :

1. Kualitas Layanan (X1)

Terlihat bahwa $t$ hitung Kualitas Layanan adalah 3.952 sedangkan $t$ tabel diperoleh sebesar 1.985 dan variabel Kualitas Layanan memiliki nilai signifikan sebesar $0.000<0.05$ artinya signifikan, sedangkan thitung > ttabel, (3.952> 1.985) maka Ha diterima dan H0 ditolak, sehingga dapat disimpulkan bahwa Kualitas Layanan secara parsial berpengaruh signifikan terhadap Minat Beli Onlinepada Mutiara Sendang Lamongan

2. Citra Merek (X2)

Terlihat bahwa t hitung Citra Merek adalah 4.201sedangkan $\mathrm{t}$ tabel diperoleh sebesar 1.985 dan variabel Citra Merek memiliki nilai signifikan sebesar $0.000<0.05$ artinya signifikan, sedangkan thitung > ttabel, (4.201> 1.985) maka Ha diterima dan H0 ditolak, sehingga dapat disimpulkan bahwa Citra Merek secara parsial berpengaruh signifikan terhadap Minat Beli Online pada Mutiara Sendang Lamongan

\section{Kepercayaan(X3)}

Terlihat bahwa $t$ hitung Kepercayaan adalah 4.151sedangkan $\mathrm{t}$ tabel diperoleh sebesar 1.985 dan variabel Kepercayaan memiliki nilai signifikan sebesar $0.000<0.05$ artinya signifikan, sedangkan thitung > ttabel, (4.151> 1.985) maka Ha diterima dan H0 ditolak, sehingga dapat disimpulkan bahwa Kepercayaan secara parsial berpengaruh signifikan terhadap Minat Beli Online pada Mutiara Sendang Lamongan

b. Uji F

Tabel 8 Uji F ${ }_{\text {ANova }}{ }^{3}$

\begin{tabular}{|ll|r|r|r|r|r|}
\hline Model & & Sum of Squares & \multicolumn{1}{c|}{ df } & Mean Square & F & \multicolumn{1}{c|}{ Sig. } \\
\hline 1 & Regression & 326.478 & 3 & 108.826 & 85.231 & $.000^{\circ}$ \\
& Residual & 121.300 & 95 & 1.277 & & \\
& Total & 447.778 & 98 & & & \\
\hline
\end{tabular}

b. Predictors: (Constant), Kepercayaan, Kualitas Layanan, Citra Merek

Sumber : Data Primer diolah 2020

Dari tabel diatas hasil uji F maka dapat disimpulkan nilai signifikasi $0.000<0.05$ dan nilai $\mathrm{F}$ hitung 85.231> F tabel 2.47 maka H0 ditolak dan $\mathrm{Ha}$ diterima. Hal ini menunjukkan bahwa variabel independen Kualitas Layanan (X1), Citra Merek (X2), dan Kepercayaan(X3) berpengaruh secara simultan terhadap variabel dependen Minat Beli Online(Y) pada Mutiara Sendang.

c. Uji Koefisien Determinasi (R2)

Tabel 9 Uji F

\begin{tabular}{|c|c|c|c|c|c|c|c|c|c|c|}
\hline \multirow[b]{2}{*}{ Model } & \multirow[b]{2}{*}{$\mathrm{R}$} & \multirow[b]{2}{*}{$\begin{array}{c}\mathrm{R} \\
\text { Square } \\
\end{array}$} & \multirow{2}{*}{\begin{tabular}{|c|} 
Adjusted \\
$R$ \\
$R$ \\
Square \\
\end{tabular}} & \multirow{2}{*}{$\begin{array}{c}\text { Std. Error } \\
\text { of the } \\
\text { Estimate } \\
\end{array}$} & \multicolumn{5}{|c|}{ Change Statistics } & \multirow[b]{2}{*}{$\begin{array}{l}\text { Durbin- } \\
\text { Watson }\end{array}$} \\
\hline & & & & & $\begin{array}{l}\text { R Square } \\
\text { Change }\end{array}$ & F Change & dfi & $\mathrm{df} 2$ & \begin{tabular}{|c|} 
Sig. F \\
Change
\end{tabular} & \\
\hline 1 & $.854^{3}$ & .729 & .721 & 1.130 & .729 & 85.231 & & \begin{tabular}{|c|}
95 \\
\end{tabular} & .000 & 1.679 \\
\hline
\end{tabular}

b. Predictors: (Constant), Kepercayaan, Kuflent Variable: Minat Beli Online

Sumber : Data Primer diolah 2020

Dari tabel diatas diperoleh nilai Adjusted R Square sebesar 0.721 atau 72,1\% pengaruh variabel kualitas Layanan, Citra Merek dan Kepercayaan. Sedangkan sisanya sebesar $27,9 \%$ dipengaruhi oleh variabel lain diluar penelitian.

\section{KESIMPULAN}

Berdasarkan hasil penelitian dalam skripsi ini, maka dapat ditarik simpulan sebagai berikut : 
1. Variabel Kualitas Layanan (X1) secara parsial berpengaruh positif dan signifikan terhadap Minat Beli Online pada Mutiara Sendang Lamongan Hasil pengujian dilihat dari uji $\mathrm{t}$ (parsial), bahwa nilai thitung > ttabel maka Ha diterima dan H0 ditolak.

2. Variabel Citra Merek (X2) secara parsial berpengaruh positif dan signifikan terhadap Minat Beli Online pada Mutiara Sendang Lamongan Hasil pengujian dilihat dari uji $\mathrm{t}$ (parsial), bahwa nilai thitung > ttabel maka Ha diterima dan $\mathrm{H} 0$ ditolak.

3. Variabel Kepercayaan $(X 3)$ secara parsial berpengaruh positif dan signifikan terhadap Minat Beli Online pada Mutiara Sendang Lamongan Hasil pengujian dilihat dari uji $\mathrm{t}$ (parsial), bahwa nilai thitung > ttabel maka Ha diterima dan H0 ditolak.

4. Variabel Kualitas Layanan, Citra Merek dan Kepercayaan secara simultan berpengaruh positif dan signifikan terhadap Minat Beli Online pada Mutiara Sendang Lamongan Dapat dilihat dari uji $\mathrm{F}$ yang menunjukkan bahwa nilai Fhitung $>$ Ftabel .

5. Variabel bebas yang lebih dominan dalam mempengaruhi Minat Beli Online pada Mutiara Sendang Lamongan adalah Citra Merek, yang diperoleh dari hasil uji $t$ atau secara parsial

\section{SARAN}

Berdasarkan kesimpulan diatas, ada beberapa saran yang diajukan oleh penulis :

1.Diharapkan kepada perusahaan Mutiara Sendang Lamongan. dalam hal ini harus selalu meningkatkan strategi pemasaran usaha inovasi online di tengah persaingan usaha, dan perlu fokus pada strategi Kualitas Layanan, Citra Merek, dan Kepercayaan terhadap Minat Beli Online konsumen

2.Diharapkan untuk penelitian selanjutnya selain faktor-faktor Kualitas Layanan, Citra Merek dan Kepercayaan yang berpengaruh terhadap Minat Beli Online. Penelitian ini belum memasukkan variabel yang lain yang mungkin dapat mempengaruhi dan menyempurnakan hasil penelitian ini

\section{DAFTAR PUSTAKA}

Basu Swastha, I. (2008). Manajemen Pemasaran Modern. Yogyakarta: Liberty.
Fandy Tjiptono . 2015. Strategi Pemasaran, Edisi 4, Penerbit Andi, Yogyakarta

Ghozali, Imam, 2013, Analisis Multivariant SPSS : Undip, Semarang

Griffin Ronald J. Ebert, 2013. Edisi Kedelapan. BISNIS. Memahami Proses Pemasaran Dan Perilaku Konsumen. Salemba Empat : Jakarta

Kotler dan Keller. 2009. Manajemen Pemasaran. Jilid I. Edisi ke 13 Jakarta: Erlangg.

Kotler, Philip, 2011, Marketing Management: Analysis, Planning, Implimentation and Control, 10th ed. Englewood Cliffs, NJ : Prentice Hall

Kotler Philip, Amstrong Gary. 2013. Prinsipprinsip Pemasaran, Edisi ke-12. Penerbit Erlangga

Lupiyoadi, R. (2013). Manajemen Pemasaran Jasa Berbasis Kompetensi (Edisi 3). Jakarta: Salemba Empat.

Lee, HJ. \& Kang, MS. (2012). The Effects of Shopping Orientations, Online Trust and Prior Online Purchase Experience toward Customers ' Online Purchase Intention. International Business Research, 3(3), 63-76.

Mauludin, Hanif, 2010, Marketing Research: Panduan Bagi Manajer, Pimpinan Perusahaan Organisasi, Penerbit Elex Media Komputindo Jakarta

Nanda Bella Fidanty Shahnaz, Wahyono 2016. Faktor yang mempengaruhi Minat Beli konsumen di Toko online Management Analysis Journal https://journal.unnes.ac.id/sju/index. $\mathrm{php} / \mathrm{maj} /$ article/download/5571/774 3

Setiadi, N. J. (2008). Perilaku Konsumen: Konsep dan Implikasi untuk Strategi dan Penelitian Pemasaran. Jakarta: Kencana

Sumarto (2010) Pentingnya Brand Loyalty terhadap Minat Beli Ulang, Jurnal ekonomi

Sugiyono, 2010. Metode Penelitian Bisnis. Bandung: Alfabeta.

Sugiyono, 2012. Metode Penelitian Bisnis. Bandung: Alfabeta.

Siti Maliyah (2015).Pengaruh citra merek, kepercayaan (trust) dan komitmen terhadap loyalitas nasabah pada PT. Henan putihrai asset management. Jurnal Ilmiah Manajemen dan Bisnis, 
Pengaruh Kualitas Layanan ,Citra Merek Dan Kepercayaan ..

Ahmad Fathur Rozi, Nasikan

Universitas Ibnu Khaldun

https://media.neliti.com/media/publi

cations/96732-ID-pengaruh-citra-

merek-kepercayaan-trust-d.pdf

Tjiptono, Fandy. (2008). Strategi Pemasaran.

Yogyakarta: Andi Offset

Tjiptono, Fandy., 2015. Strategi Pemasaran,

Edisi 4, Penerbit Andi, Yogyakarta

Tatik Suryani, Perilaku Konsumen Implikasi

Pada Strategi Pemasaran, (Yogyakarta:

Graha. Ilmu, 2008) 